\title{
Willem Verbeke \\ Advertising, Product Quality, and Complex Evolving Marketing Systems
}

\begin{abstract}
The paper analyses the "advertising as power" vs. "advertising as information" controversy as well as its recent empirical testing. It is stressed that this distinction focuses too much on the interaction between consumer and manufacturer while ignoring the retailer as an important stake-holder. To compensate for this lack, a complex marketing system perspective is introduced in which consumer, retailer, and manufacturer interact. However, these complex marketing systems might drift towards market equilibria which are against the consumer interests: that is, firms might lock out brands from the market by means of trade and sales promotions and then use advertising to protect their position. Consequently brands of better quality and/or innovative brands are barred from trade shelves.
\end{abstract}

The relationship between advertising and product quality and their linkage to market structures have recently become the focus of attention for two reasons: (a) we have witnessed a renewed interest in product quality from academics as well as manufacturers and (b) the productivity of advertising continues to attract the attention of many major media, for example US News and World Report (Allman, 1989) and The New York Times (Rothenberg, 1989).

This paper will first elucidate the controversy concerning the relationship between quality and advertising. This controversy began when two theories about advertising and market structure emerged: The first theory saw advertising as information (Nelson, 1970) and the second saw advertising as power (Comanor \& Wilson, 1974). Next, an empirical test of both models by Tellis and Fornell (1988) will be analysed. Some deficiencies of this empirical study will be discussed and an alternative theoretical model which borrows from "complex systems theory" will be presented. This new model, so I suggest, can serve as a framework for discussing consumer policy issues as regards advertising. 
THE THEORIES

\section{Advertising as Information}

In his discussion of the relationship between advertising and product quality, Nelson $(1970,1974)$ introduces two main theses concerning consumer behaviour:

1. Advertising essentially informs consumers about product attributes, but does not change the way consumers value those attributes.

2. Over time, consumers become more price sensitive and subsequently buy best "value." The relationship between price and quality, as assessed by consumers, in particular affects the elasticity of a given product.

It is because the consumer is able to evaluate product quality that certain dynamics will develop in markets. Two specific dynamic processes are generated:

1. Better informed consumers pressure firms to lower prices and improve quality. Firms able to improve product quality can enter the market.

2. Over the product's life cycle, industry prices will decrease; profits are affected by increased competition; the effect on profits resulting from increased efficiency is ambiguous.

As a result of these dynamics, a specific market structure subsequently emerges: Entry into a market is always possible because firms can produce innovative product attributes and communicate these to consumers, which will intensify the competition. Within an industry, only efficient firms will survive. Inefficient firms will be replaced by the innovative entrants.

Nelson's point of view has also been suppested by Akerlof (1970) who claims that branding of goods (in which advertising plays a crucial role) signalises quality, thus reducing consumer uncertainty about quality. The brand becomes a signal because consumers know that brands which do not meet the consumer expectations (called lemons) have been, or should have been, eliminated.

\section{Advertising and Market Power}

The theory of Comanor and Wilson (1974) is based upon other presumptions concerning consumer behaviour:

1. Advertising affects consumer preferences and tastes, changes 
product attributes, and differentiates the product from competitive offerings.

2. Consumers become brand loyal because of advertising and, as a result, become less price sensitive, thus perceiving fewer substitutes for advertised brands.

Market dynamics are affected by this consumer behaviour in three ways:

1. Firms can charge higher prices and are not as likely to compete with quality or price.

2. Innovation within firms may be reduced,

3. High prices and excessive profits might accrue to firms which sell advertised but low quality products, giving them even more incentive to advertise their products.

These changes in market dynamics generate a market structure in which potential entrants must overcome established brand loyalty and spend relatively more on advertising. Consequently, established firms can insulate themselves from market competition by outspending rivals, both present and potential. As a result, few firms will dominate the industry, leaving them with much discretionary power.

Comanor and Wilson's picture of how advertising works is just the opposite of Nelson's. In their view, firms are able to sell products of lower quality because advertising develops brand loyalty. Consequently, when firms sell more and also earn more by making consumers less price sensitive, they will invest in advertising rather than in product improvement or innovation (a thesis which Nelson seems to reject, as he states that innovation is the central source of changes in the marketplace). Furthermore, firms with products of better quality may be unable to enter the market because they cannot afford the advertising needed to overcome the existing brand loyalty.

\section{An Assessment of the Two Theories}

- The authors of both theories concentrate on only a small percentage of marketing communications; they do not mention other communication tools, such as sales and trade promotions. Currently, advertising represents only $30 \%$ of the marketing communication budgets while trade promotion represents $40 \%$ and sales promotion 30\% (Farris \& Quelch, 1987).

- Neither theory mentions the emerging power of the retailing trade (a subject which will be discussed below). In other words, their 
proponents exclusively study the direct effects of advertising on consumer buying behaviour. This method of analysis is called "single stage modelling" (Steiner, 1978).

- The direct and indirect effects of advertising on traders are crucial in determining profits. Advertising results in a reduction of the trade's margin (because retailers engage in interstore competition and the price of salient brands subsequently drop), but the margin of the manufacturer remains unaffected. The profits which then emerge can and will be used for product innovations. This observation is not consistent with the statement of Comanor and Wilson that firms must constantly invest in advertising to secure their market share.

- It is difficult to describe advertising by means of the budget only. Creativity and quality of advertising copy play a role as well, and neither Nelson nor Comanor and Wilson seem to address this issue.

- Although both theories describe how firms bring brands onto the market, these descriptions are somewhat superficial. Most firms bring a portfolio of brands to the marketplace with some brands serving as cash cows to support the newly introduced brands. Firms which buy advertising for a brand portfolio also benefit from economies of scale. While Comanor and Wilson state that firms with a high market share will invest more in advertising than their competitors, they do not mention that this may also be attributable to the economies of scale. It is economies of scale (and the profits generated because of the high margins) that allow firms to invest more money in product development and innovation. Nelson's theory, too, seems to ignore these effects.

- Nelson states that advertising does not change consumer perceptions of the brand. However, firms develop brand portfolios based on positioning strategies which are amplified by advertising campaigns and which give rise to specific images in the consumer's mind (Wind, 1982).

- Nelson argues that advertising informs consumers. However, already in 1971, Morris proved that neither the company's nor the brand's image can be regarded as a valid and reliable indicator of quality and price (whereas comparative product testing provides more though not totally accurate indicators of quality).

I am in full agreement with Tellis and Fornell (1988) that these two theoretical models, which supposedly set out to explain the occurrence of advertising, include many unsubstantiated assumptions 
that themselves have contributed to the controversy about the role of advertising in consumer behavior. For instance, it has not been substantiated that advertising makes people brand loyal (as Comanor and Wilson state); nor has it been substantiated that advertising fails to change people's perceptions of brands (as Nelson states). I will now describe the way in which Tellis and Fornell seek to verify the above-mentioned models empirically.

\section{The Empirical Test of the Advertising Controversy}

Tellis and Fornell (1988) begin by introducing operational definitions of the terms used in the two models. They then introduce two new aspects of consumer behaviour, thus expanding the possible dynamics which advertising can initiate within markets. These dynamics can be described as follows:

1. Over time, consumers can be (and are) informed about product quality from different sources, such as mouth-to-mouth communication, personal experience, consumer groups, and consumer magazines.

2. Improved product quality is not necessarily related to higher costs in the beginning of the product life cycle since the firm might have in-house expertise which allows it to enter a new market without heavy investment.

After introducing these ideas, Tellis and Fornell then reformulate the two paradigms mentioned earlier. Nelson's "advertising is information" theory is now viewed as a theory about efficient market structures. Comanor and Wilson's "advertising is power" is now perceived as a theory about perverse market structures.

Advertising and efficient markets. This scenario postulates that some firms, already experienced in marketing similar products or possessing established know-how, can enter new markets relatively easily. It also assumes that consumers are reasonably well informed about quality and are willing to pay more for better quality; hence firms with brands of higher quality will attract a larger market. Assuming this is true, companies with higher quality brands will be motivated to increase advertising. Therefore, higher quality will lead to higher levels of advertising, market share, and profit. 
for some firms, to produce quality products. Furthermore, if consumers are not informed about quality or are unable to recognize it, they will not pay for it. As a result, consumers are more responsive to advertising. Given this scenario, firms producing low quality brands will succeed by advertising heavily and will, by investing in advertising but not in product quality, force the quality producers out of the market. Lower quality products (lemons) and increased advertising will result.

Tellis and Fornell (1988) have tested both scenarios using a product life cycle (PLC) approximation. They hypothesize that markets may behave in a perverse manner in the beginning of the PLC, but will become more efficient over time. In the beginning of the PLC, consumers have not yet formed an opinion of the product. Consequently, consumers will respond less intelligently to advertising (advertising works perversely). At the end of the PLC, consumers will be better informed about product quality (which makes them less responsive to advertising) and, because firms are able to produce quality more efficiently, markets will be more competitive. Using the PIMS data base, Tellis and Fornell (1988) indeed verify that markets become more efficient over time: "Public policy makers need not be greatly concerned by advertisers' expenditures per se for overall consumer welfare. Markets in the aggregate appear fairly competitive, as the positive rewards to quality indicate" (p. 70).

\section{THE RETAILER AS A MARKETING STAKE-HOLDER, OR THE NEED} FOR DUAL-STAGE MODELS

As mentioned above, Tellis and Fornell expanded the quality versus advertising discussion by arguing that consumers are able to recognize product quality and that firms in some instances are able to produce high quality products at relatively low costs - dynamics which would result in efficient markets. Tellis and Fornell's model must also be classified as a single-stage model however, since it does not deal with the behaviour of the retailer. Nowadays, most scholars agree that single-stage models are incomplete since the retailer has become a crucial stake-holder substantially affecting market dynamics (Farris, Olver, \& DeKluyver, 1989). The retailer is a powerful marketing stake-holder for the following reasons:

1. Shelf space, owned by the retailer, may be an even more important factor than modern marketing techniques, shelf space 
being the more limited resource. Current brand extensions only add to this problem.

2. By becoming heavily concentrated, the retailing trade strengthened its bargaining power. This phenomenon explains rising manufacturer expenditures on trade promotions.

3. The retailing trade learned to improve their shelf space management by means of new techniques, such as the DPP (Direct Product Profitability) and DPC (Direct Product Costs) models. This gave the trade increased power during negotiations with the manufacturers.

These trends spurred scholars to develop dual-stage models in which there are interactions between consumer, retailer, and manufacturer. The following studies can be characterized as dual-stage models.

Farris et al. (1989) showed that brands that obtain an advantage in the beginning of the PLC (perhaps due to trade marketing efforts) regularly obtain better distribution and higher market share over time. The trade adopts and keeps brands with higher turnover (DPP and DPC models show that brands with a high turnover are cost efficient for the trade). Brands which sell well initially, will generate advertising funds which help increase further sales and secure their place on the shelves. Farris and Reibstein (1984) described this phenomenon as follows: "Changes in advertising can cause changes in distribution; changes in demand can cause changes in distribution; and changes in distribution can change sales" (p. 33). A former manager of a fast moving multinational company made the following observation: "to come back to your question ... about buying shelf space: we simply bought shelf space. Rest the question what perfect competitive markets really mean" (de Soet, 1989 , p. 6). Numerous studies show that when adopting new products, established firms have an advantage over others (Gupta, 1988).

Firms with brands which are established in the stores will also practise account management and relationship management. That is, they will invest in establishing a good relationship with the retailer and when competitors introduce a new product they will imitate the new product and preempt shelf space (Heeler, Kearney, \& Mehaffey, 1973).

Although consumers do evaluate brands, this evaluation does depend on context. As many scholars have observed, store loyalty is frequently due to advantageous location and convenience (Carman, 
1970; Farris et al., 1961; Kuehn, 1961). Consequently, consumers choose among brands available at that store. Other studies show that consumers barely remember prices (prices change too often) and perceive a brand as price reduced when placed on display (even when the price has actually not been reduced) (Dickson \& Sawyer, 1990). Furthermore, studies in connectionistic psychology (Smolensky, 1988) show convincingly that consumers are input sensitive, which implies that their perceptions of brands fluctuate constantly depending on the context (also called "impulsive" buying).

The PIMS data base, which Tellis and Fornell have been using, has an inherent bias: Firms forced out of the market or unable to enter the market due to limited shelf space even though they may produce higher quality products, are not included in the data base since the data base includes only firms that have survived.

To achieve increased bargaining power with manufacturers, the retailers are merging. As a consequence, manufacturers are also merging. This reciprocal merging process explains the concentrations within industries, Comanor and Wilson have noted, in a different way. The mechanisms of retailer intervention in the market are not mentioned by Nelson, Comanor and Wilson, or Tellis and Fornell, which indicates that the retailer has not been perceived as an important marketing stake-holder. Now we will explore dual-stage frameworks which include the behaviour of the retailer. With both the retailer, the consumer, and the manufacturer participating, the opportunities for interactions increase significantly. Complex systems theory becomes essential for explaining why certain interactions are dominant.

\section{ADVERTISING AND COMPLEX MARKETING SYSTEMS}

I now want to introduce the hypothesis that understanding of the retailing trade becomes crucial because it conditions market dynamics. When the retailer, the consumer, and the manufacturer interact, a business system emerges. The initial conditions of a system, combined with early random events or fluctuations, act to push the system into an asymptotic state. In other words, a possible equilibrium state is selected which the system locks into (Nicolis \& Prigogine, 1989). This phenomenon, also called positive feedback, plays a creative or self-organising role within complex systems. By 
the same token, small changes may destabilise the system, after which it may settle into a state of equilibrium that is qualitatively different. As Arthur (1988, 1990) points out, economic development could well be modeled from a complex systems theory perspective. In this perspective, the economy is characterised by:

1. Multiple equilibria whose outcome is not uniquely predictable (also called an "open future").

2. Possible inefficient economic equilibria. Some technologies, firms, products, or brands may simply have bad luck in the beginning of the PLC and might subsequently fail to make it in the market.

3. Once achieved, it may be difficult to exit from equilibria.

4. Systems vulnerability. That is, innovations or changes in one of the stake-holders may destroy the system's equilibrium. That is why firms must proactively respond to these changes. In other words, the system is constantly recreating itself (Nicolis \& Prigogine, 1989).

Arthur's example of the VHS and Beta case is illuminating. In the beginning of the PLC, Beta and VHS both competed for market dominance. However, a small lead in the market share gained by one of the technologies could enhance its competitive position and help it to increase its lead. For instance, because VHS was found in more video stores, more VHS recorders were bought. Increased VHS recorder sales led to increased VHS tape sales, thus creating a selfreinforcing process that eventually captured $100 \%$ of the market. This phenomenon is called positive feedback. Arthur argues that this process could be called coordination: As a product obtains high distribution, consumers most likely will choose among these products so distributed. This self-reinforcing mechanism is important for marketing and confirms the previous argument about the crucial role the retailer plays in markets. While consumers acted quite rationally in the video recorder scenario (they bought videos and recorders which were easily obtained and of satisfactory quality), other manufacturers were forced to produce recorders using the VHS standard. Consequently, since most experts agreed that Beta was of better quality, the total market did not evolve into its most efficient state. This self-organising process, by means of which a total market drifts into an inefficient equilibrium, is called "competition as collusion" by Hirschman (1970). In short, complex systems theory emphasises the self-organising process which might lead to various equilibria states, states which are not necessarily the most efficient ones from the consumer's point of view. 
The Beta and VHS case which was used to exemplify a complex systems perspective is a case at the product standard level, not at the brand or firm level. Nevertheless, Arthur's case is an interesting example, because it illustrates the self-organising process within the market and how market inefficiencies might occur. Below, I will concentrate mainly on how firms might lock out other firms (and their brands and innovations) from markets by means of marketing communication, with resulting inefficiencies from the consumer's point of view.

Before I continue, two aspects are now recapitulated:

1. In the criticised theories, too few marketing stake-holders were included, thus setting a limit to the number of possible end states or equilibria.

2. Manufacturers merge because retailers merge and vice versa. Subsequently, fewer firms are marketing more brands thus allowing them to obtain economies of scale and other benefits.

From the complex systems perspective, successful firms gain market share because they are able to co-ordinate the marketing stake-holders (consumers, retailers, and competitors), thus reducing for some time the degrees of freedom within a market. In marketing, this coordination process is called "environmental shaping" (Savitt, 1987). Manufacturers will offer brands that fit the consumer needs (to a certain degree) while trying to keep competitors out of the market by limiting their shelf space. Manufacturers create this sort of environment with advertising (and other communication tools). But as we will see, this new environment generates dynamics which not only lock up a system (through entry barriers) but also create instabilities. The main components of this complex systems perspective can be described in the following way:

- Manufacturers who have established a good relationship with retailers have a competitive advantage in the beginning of the PLC when markets have not yet reached an equilibrium. These same firms also use their advertising budget (actual as well as projected) to assure adoption of their brand by the trade (Farris \& Reibstein, 1984). Furthermore, their advertising campaigns create consumer preferences which reinforce their security (see Figure 1).

- When consumers buy a product, these same consumers become more sensitive to the brand's advertising. As they become more sensitive to the advertising, increased buying results, which then leads to a higher market share (Tellis, 1988) thus positively influenc- 


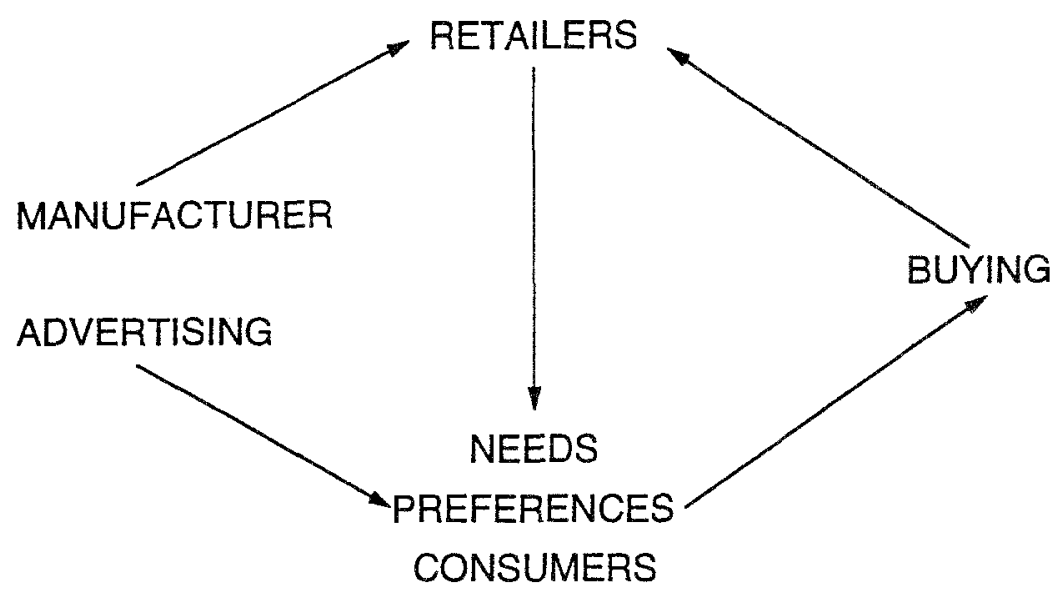

Fig. 1. The effects of advertising on retailers and consumers.

ing the adoption by the trade. Notice that where Comanor and Wilson suggest that consumers become brand loyal, it is now suggested that consumers become more sensitive to the advertising of their chosen brands (advertising prone) which results in more buying.

- When brands become more popular or salient, stores reduce their prices (called interstore competition) (Albion, 1983). This lowering of prices further increases the sale of the brand, thus making leaders stronger. However, this mechanism also reduces the margin of the retailers who, in reaction, might introduce their own brands (called private brands). This new marketing game reduces competition within an industry because it reduces shelf space available to the manufacturers. In other words, the marketing generates new dynamics.

- The retailer is also active in: (a) positioning himself as a high quality purveyor or as a discounter (which subsequently affects which brands will be adopted); (b) proactively introducing his own innovative brands. In fact, retailers are the biggest advertisers, at least in Europe. These trade activities also lead to new dynamics in the markets.

- Last but not least, the consumer (tastes, buying patterns, etc.) is changing too. The retailer as well as the manufacturer will respond to these changes ex post as well as ex ante. These reactions also generate instabilities in the current system. 
I have just explained how the behaviour of the various marketing stake-holders might inject instabilities into the system which, amplified over time, may lead to new temporarily stable equilibria. In other words, the system renews itself constantly. These mechanisms might, in some cases, create inefficiencies in markets (which the VHS case illustrates). The highest quality products will not always reach the consumer, either because the trade has not adopted the best quality brand, or because other firms have tilted the market to an equilibrium unfavourable to products of higher quality. It must be mentioned, however, that these scenarios, while possible, are not inevitable.

THE ADVERTISING AND QUALITY DISCUSSION FROM THE SYSTEMS PERSPECTIVE

An outline has just been given of how various market stake-holders can generate new dynamics within markets. Complex systems theory shows how markets might equilibrate and how they might transform themselves over time. Now it is possible to take another look at the earlier discussion on advertising and quality.

The dynamics which Comanor and Wilson have described are apparently too narrow. The high concentration of firms which occurs in many industries cannot be attributed solely to the consumers' brand loyalty but must also be attributed to positive feedback mechanisms which operate between the retailer, the consumer, and the manufacturer. Furthermore, concentration within an industry does not imply that innovation in product and quality ceases. As we just showed, because systems are unstable, innovation and improved quality are grounds for renewed competition. Even so, inefficiencies occur.

Neither are Nelson's arguments exactly correct. The consumer might assess brands, but this evaluation process does not imply that the best brands will be retained. Some brands are simply not stocked by certain stores and therefore cannot be inspected. Furthermore, the so-called price dynamics, which consumers supposedly generate, are not really attributable to the consumer - the trade also evokes interstore competition thus lowering the retail price. This pricing, however, need not affect the manufacturer and subsequently does not lead to the market efficiency that Nelson assumes. 
The complex systems approach does not speak for Tellis and Fornell either. Their study did not really focus on the dynamics between retailer and manufacturer. As just mentioned, those dynamics might explain the higher profits of the manufacturer. Their study, based on PIMS data, did not include an investigation into how firms can be locked out of the market because of limited shelf space.

Briefly stated, the complex systems theory I have just described tells a different story of how quality, advertising, and market structures relate to one another. In this story, more interactions are possible. Consequently, a more detailed picture is called for.

\section{COMPLEX SYSTEMS AND CONSUMER POLICY}

That markets might drift into inefficient equilibria due to the interactions between retailer, manufacturer, and consumer has implications for consumer policy. The following case is well-suited to illustrate these implications.

In the Netherlands, the detergent market is a quasi-oligopolistic market dominated by three manufacturers. About five years ago a small Dutch firm invented the compact or condensed detergent. Although this innovation had benefits both for the consumer (a compact detergent takes up less room), for the environment (the smaller packaging is environment-friendly), and for the trade (a compact detergent saves shelf space and thus hikes the DPP), once invented the compact detergent was not adopted because the reputation of this small firm as a strong brand builder was not good enough. Two years later, a Japanese firm introduced the compact detergent and before long all three major firms did likewise. The compact detergent was then quickly adopted by the retailers. Before long, the three main firms dominated the compact detergent segment.

This case shows that while the innovation did reach the market, it became significantly delayed. In other words, the market dynamics of a concentrated market might postpone the adoption of innovations among consumers. Let us remember, however, that the opposite might also occur. In many cases, the ability of multinationals to innovate and to anticipate trends far exceed consumers' current tastes and perceptions. Nevertheless, let us stick to the situation with fast moving consumer products and with the inefficient equilibria which might be generated in such markets. 
Experts in the field of consumer affairs and consumer law ${ }^{1}$ agree that these dynamics indeed might occur within consumer markets. Specifically, they point out that the introduction of ecologically responsible products might be delayed, in the same manner as some innovative products. Other examples are the non-exploitation of patented medical innovations and law suits that try to force the retailing trade to stop boycotting certain products (such as oranges from South Africa). However, the same experts suggest that it is not always desirable or possible to construct laws that can prohibit these dynamics. The experts view it as difficult to urge retailers to take actions for which they must bear the risks.

While it is true that legislative regulation of these dynamics is difficult, they have not gone unnoticed by consumer organisations. In the past, for example, a certain presence in the market (a certain market share or distribution) has been a prerequisite for a firm to be selected for the "comparative product quality test" (see also Morris $\&$ Bronson, 1969). Now certain consumer groups (the Dutch Consumer's Union, for example) have expressed the opinion that this distribution or market share should be kept as low as possible. In other words, consumer groups are interested in evaluating products as soon as they enter the market. By doing so, they hope to affect the market already in the early stages of the PLC, thus avoiding undesirable dynamics.

\section{CONCLUSION}

In this paper, reference was made to the traditional discussion between quality, advertising, and market structures. Then, in accordance with Tellis and Fornell, the discussion was expanded by introducing further marketing stake-holders, specifically the retailing trade. In this perspective, market dynamics might generate equilibria that are contrary to consumers' interests. While it is difficult to implement laws that put an end to these dynamics, consumer groups could attempt to neutralise them.

\section{NOTE}

1 The author wishes to thank W. Slagter, R. Holzhauer, W. Dolman, and L. Bakker from the Erasmus University Rotterdam and $T$. Recter from the Dutch Consumer Association for discussions about these issues. 


\section{REFERENCES}

Akerlof, G. (1970). The market for "lemons": Quality uncertainty and the market mechanism. Quarterly Journal of Economics, 89, 488-500.

Albion, M. (1983). Advertising's hidden effects. Boston: Auburn House.

Allman, B. (1990). Science 1, advertisers 0. US News and World Report, May, p. 61.

Arthur, B. (1988). Self-reinforcing mechanisms in economics. In: P. Anderson, K. Arrow, \& D. Pines (Eds.), The economics as an evolving complex system, pp. 9-31. New York: Addison Wesley.

Arthur, B. (1990). Positive feedbacks in the economy. Scientific American, No. 263, pp. $92-99$.

Carman, J. (1970). Correlates of brand loyalty: Some positive results. Journal of Marketing Research, 7,67-76.

Comanor, W., \& Wilson, T. (1974). Advertising and market power. Cambridge, MA: Harvard University Press.

de Soet, J. (1989) Betere waar en 15\% korting (Better goods and 15\% reduction). Nieuwstribune, November 30, pp. 6-7.

Dickson, P., \& Sawyer, A. (1990). The price knowledge and search of supermarket shoppers. Joumal of Marketing, 64(3), 42-53.

Farris, P., Olver, J., \& deKluyver, C. (1989). The relationship between distribution and market share. Management Science, 8, 131-148.

Farris, P., \& Quelch, J. (1987). Advertising and promotion management. Malabar: R. E. Krieger.

Farris, P., \& Reibstein, D. (1984). Over control in advertising experiments. Joumal of Advertising, 24(3), 37-44.

Gupta, P. (1988). Marketing wars - Strategy in action. In: De Praktijk van Denken en Doen, pp. 65-66. Amsterdam: NIMA Congres Jaarboek.

Heeler, R., Kearney, M., \& Mehaffey, B. (1973). Modelling supermarket product selection. Journal of Marketing Research, 10, 34-37.

Hirschman, A. (1970). Exit, voice, and loyalty. Cambridge, MA: Harvard University Press.

Kuehn, A. (1961). A model for budgeting advertising. In: F. Bass et al. (Eds.), Mathematical models and methods in marketing, pp. 315-348. Homewood, IL: Irwin.

Morris, R. (1971). Major firms comparatively evaluated. Journal of Consumer Affairs, 5, 119-139.

Morris, R., \& Bronson, C. (1969). The chaos of competition indicated by Consumer Reports. Journal of Marketing, 33, 26-34.

Nelson, P. (1970). Information and consumer behaviour. Journal of Political Economy, 78, 311-329.

Nelson, P. (1974). Advertising as information. Journal of Political Economy, 81, $729-754$.

Nicolis, G., \& Prigogine, I. (1989). Exploring complexity. New York: W. H. Freeman.

Quelch, J. (1989). How to market to consumers. New York: Wiley.

Rothenberg, R. (1989). Shifts in marketing strategy jolting advertising industry. New York Times, October 3, pp. a1/d22/d23.

Savitt, R. (1987). Entrepreneurial behaviour and marketing strategy. In: A. Firat, N. Dholakia, \& R. Bagozzi (Eds.), Philosophical and radical thought in marketing, pp. 307-322. Cambridge, MA: Lexington Books.

Smolensky, P. (1989). Connectionistic modeling: Neural computation/mental con- 
nections. In: L. Nadel, L. Cooper, P. Culicover, \& R. Harnish (Eds.), Neural connections, mental computation, pp. 49-67. Cambridge, MA: MIT Press.

Steiner, R. (1978). A dual stage approach to the effect of brand advertising on competition and price. In: J. Cady (Ed.), Marketing and the public interest, pp. 127-150. Cambridge, MA: Marketing Science Institute.

Tellis, G. (1988). Advertising exposure, loyalty, and brand purchase: A two-stage model of choice. Journal of Marketing Research, 25, 134-144.

Tellis, G., \& Fornell, C. (1988). The relationship between advertising and quality over the product life cycle: A contingency theory. Journal of Marketing Research, $25,64-71$.

Wind, Y. (1982). Product policy: Concepts, methods, and strategy. Reading: AddisonWesley.

\section{ZUSAMMENFASSUNG}

Werbung, Produktqualität und komplexe Marketingsysteme. Der Beitrag behandelt die kontroverse Gegenüberstellung von Werbung als Marktmacht und Werbung als Information, sowie einen neueren Versuch, diese Kontroverse empirisch zu entscheiden. Der Autor betont, daß sich die Kontroverse zu stark auf die Interaktion zwischen Konsument und Hersteller konzentriert, während der Handel als eigenständig beteiligte Instanz übersehen wird. Um diesen Mangel zu beheben, führt er eine komplexere Perspektive des Marketingsystems ein, in welcher alle drei Instanzen interagieren. Die Analyse ergibt jedoch, daB sich solche komplexe Marketingsysteme auf Gleichgewichte zubewegen können, die gegen das Konsumenteninteresse gerichtet sind. Unternehmen können Konkurrenten mit handelspolitischen Maßnahmen vom Markt fernhalten und dann ihre eigene Position mit Mitteln der Werbung schützen. Folgich können Marken besserer Qualität oder innovative Produktenwicklungen vom Markt ferngehalten werden.

\section{THE AUTHOR}

Willem Verbeke is an Assistant Professor in the Department of Marketing, School of Economics, Erasmus University, Postbus 1738, NL-3000 DR Rotterdam, The Netherlands. 